\title{
ADHESION AND BIOCIDES INACTIVATION OF SALMONELLA ON STAINLESS STEEL AND POLYETHYLENE
}

\author{
Eduardo Cesar Tondo*, Taís Raquel Marcon Machado, Patrícia da Silva Malheiros, Débora Kruger Padrão, Ana Lyl de \\ Carvalho, Adriano Brandelli
}

Instituto de Ciência e Tecnologia de Alimentos, Universidade Federal do Rio Grande do Sul, Porto Alegre, RS, Brasil.

Submitted: September 10, 2009; Returned to authors for corrections: April 23, 2010; Approved: May 13, 2010.

\begin{abstract}
The adhesion of Salmonella $(S$.) strains to stainless steel and polyethylene and their inactivation by biocides used in food industry was investigated. Coupons of stainless steel and polyethylene were immersed in bacterial suspensions of $S$. Enteritidis, $S$. Typhimurium, and $S$. Bredeney during 15, 30, and 60 minutes, and submitted to different concentrations of peracetic acid (PAA), sodium hypochlorite $(\mathrm{NaOCl})$, and quaternary ammonium (Quat) sanitizers. Hydrophobicity of the surfaces was evaluated by contact angle measurements using the sessile drop method and bacterial adhesion was accompanied through bacterial counts and scanning electron microscopy (SEM). Results indicated that the three serovars of Salmonella presented similar adhesion to both materials (5.0 to $6.5 \mathrm{log} \mathrm{cfu} \mathrm{cm}^{-2}$ ). The time of exposure did not influence the counts of adhered cells on both surfaces, however SEM revealed larger clusters of $S$. Enteritidis on both materials, not found for the other serovars. $S$. Enteritidis presented lower sessile drop angle on polyethylene, indicating hydrophilic properties of this material. The biocides were not able to inactivate all the microorganisms adhered on both surfaces. At least $1 \log \mathrm{cfu} \mathrm{cm}^{-2}$ of all serovars tested remained viable after the exposure to different biocide concentrations. In general, higher counts of survivors were observed on polyethylene disinfected with different concentrations of biocides. $S$. Bredeney e $S$. Typhimurium were more resistant than $S$. Enteritidis to PAA, whilst $S$. Enteritidis presented smaller reduction rates to $\mathrm{NaOCl}$. This last biocide was able to reduce Salmonella counts in approximately 3.0 to $4.0 \log \mathrm{cm}^{-2}$. When adhered to polyethylene, the serovars $S$. Typhimurium and $S$. Enteritidis were more resistant to Quat than $S$. Bredeney in all concentrations tested, and the numbers of $S$. Enteritidis remained almost unaltered. On stainless steel disinfected by Quat, S. Bredeney presented higher numbers of survivors.
\end{abstract}

Key words: Salmonella; adhesion; biocides; stainless steel; polyethylene.

\section{INTRODUCTION}

Salmonellosis is an important public health problem worldwide and the control of Salmonella in food chain remains difficult. In Brazil, Salmonella has been identified as the main cause of foodborne diseases investigated by regulatory bodies, and $S$. Enteritidis has been identified as the most frequent serovar involved in foodborne outbreaks $(20,21)$. In Rio Grande do Sul (RS), Southernmost state of Brazil, a specific strain of $S$. Enteritidis (SE86) has been the causative agent of more than $90 \%$ of the salmonellosis investigated in the last years $(8,21,22)$. The factors that make this strain an important 
foodborne pathogen are still unclear, and could be related to its adhesion capacity or resistance to usual sanitizers.

Bacterial adhesion is influenced by the type of surface and its topography, considering that abrasive surfaces are more susceptible to dirt accumulation and are more difficult to clean than smoother surfaces $(7,9,17)$. Other factors such as hydrophobicity, chemical composition and the presence of proteins on the surfaces can also result in different levels of bacterial adherence $(4,11,27)$.

Stainless steel and polyethylene have been largely employed in equipments and utensils for food production, due to their resistance, durability, and easiness in the cleaning process and disinfection. However, the sanitation procedures applied on such surfaces could be not completely effective, since effectiveness depends on the type of adhered microorganisms and the properties of these surfaces (2). The choice of adequate sanitizers is very important, and must be preceded of a detailed analysis, such as its the official authorization of use, toxicity, corrosive action, residual effect in the food, environmental impact and cost (26). Peracetic acid, sodium hypochlorite and quaternary ammonium are some chemical agents that fulfill these characteristics (18).

In Brazil, sodium hypochlorite $(\mathrm{NaOCl})$ has been widely used in home and food establishments, due to its efficiency against many microorganisms and accessible cost (24). Peracetic acid (PAA) has also been frequently used, since it is very efficient to remove biofilms and causes lower environmental impact $(10,17,26)$. The use of quaternary ammonium (Quat) compounds is also very common, due to their antimicrobial properties, low toxicity and effectiveness for surfaces disinfection (18).

The aim of this work was to evaluate the adhesion of Salmonella strains, involved or not with salmonellosis, to stainless steel and polyethylene and also to investigate the ability of $\mathrm{NaOCl}, \mathrm{PAA}$ and Quat to disinfect these materials.

\section{MATERIALS AND METHODS}

\section{Bacterial strains}

Strains of Salmonella enterica of three different serovars were used in this study. S. Enteritidis strain (SE86) was isolated from cabbage involved in a salmonellosis outbreak occurred in Rio Grande do Sul (RS), in 1999. This microorganism presents the same genotypic pattern of $S$. Enteritidis strains involved in more than $90 \%$ of the outbreaks of salmonellosis occurred in the period between 1999 and 2002, in RS $(8,21)$. S. Typhimurium and $S$. Bredeney strains were chosen because they were isolated in RS State in 1999, from a pig fecal sample and from a fermented meat sample, respectively, and these Salmonella serovars rarely were involved in foodborne diseases in RS in the last years (21). The strains were stored at $-18^{\circ} \mathrm{C}$ in $50 \%$ (v/v) glycerol. They were activated by transferring $20 \mu \mathrm{l}$ of stock culture to $3 \mathrm{ml}$ of Brain Heart Infusion (BHI) (Biobras, Belo Horizonte, Brazil). Working cultures were kept at $4^{\circ} \mathrm{C}$ on Nutrient Agar (NA) (Merck, Darmstadt, Germany) plates, and before use they were transferred to Nutrient Broth (NB) (Synth, São Paulo, Brazil) and incubated for $24 \mathrm{~h}$ at $37^{\circ} \mathrm{C}$.

\section{Preparation of stainless steel and polyethylene coupons}

Stainless steel AISI 316 (0.1 cm thick) (Metalbras, Porto Alegre, Brazil) and polyethylene $(0.7 \mathrm{~cm}$ thick) (Sanremo, Esteio, Brazil) coupons of $2 \times 2 \mathrm{~cm}$ were prepared. Prior to adhesion tests, coupons were degreased with a neutral detergent $(3 \%, \mathrm{v} / \mathrm{v})$ for one hour, rinsed with $70 \%(\mathrm{v} / \mathrm{v})$ ethanol, and then washed with distillated water. The coupons were then dried at $60^{\circ} \mathrm{C}$ for two hours and autoclaved at $121^{\circ}$ C, for $15 \mathrm{~min}$ in sealed tubes (26).

\section{Coupons contamination and evaluation of Salmonella adherence}

The coupons were immersed in $10 \mathrm{ml}$ of NB containing approximately $8 \log \mathrm{cfu} \mathrm{ml}^{-1}$ of each strain separately. Three coupons of stainless steel and three coupons of polyethylene were immersed in the cultures for 15,30 , and $60 \mathrm{~min}$, without shaking, at room temperature (14). These times were chosen aiming to simulate the short time of contact of food with surfaces during food preparation. After that, the coupons were washed with PBS (phosphate buffer saline; $\mathrm{pH}$ 7.2) to remove 
the poorly adhered cells. The stainless steel coupons were immersed in $10 \mathrm{ml}$ of PBS, while the polyethylene coupons were immersed in $15 \mathrm{ml}$ of PBS before sonication process. Each coupon was submitted to sonication in a bath sonicator (UNIQUE USC 700) with frequency of $40 \mathrm{KHz}$, for 2 periods of $10 \mathrm{~min}$, for the release of adhered cells. During sonication, the temperature of PBS was monitored with a Thermometer (AKSO MULTI-Thermometer AKTD 3429) and it not exceeded $40^{\circ} \mathrm{C}$, avoiding thermal injury to Salmonella cells.

PBS containing each sonicated coupons were submitted to decimal dilutions and $20 \mu \mathrm{l}$ of each dilution were plated in NA, as described by Milles and Misra (19). The plates were incubated for 18 hours at $37^{\circ} \mathrm{C}$ and the numbers of $\mathrm{cfu} \mathrm{cm}^{-2}$ were determined. All counts were made in triplicate and each experiment was repeated twice.

\section{Hydrophobicity evaluation}

Hydrophobicity was evaluated by the sessile drop method described by Locatelli et al. (15), measuring the contact angles of the testing materials in the stainless steel and polyethylene coupons. Drops of $20 \mu \mathrm{l}$ of the cultures of each one of the three Salmonella serovars in BHI were added to the surface of cleaned and disinfected coupons and the contact angles were compared to that obtained using $20 \mu \mathrm{l}$ of distillated water. The drops were registered by a digital camera (Sony® Cyber-Shot 5MP model F707) in the photodocumentation section of the Hospital de Clínicas of Porto Alegre (HCPA) and the images were analysed in a personal computer. The contact angle was measured through the inclination of the line formed between the contact base and the drop height, larger angles meaning higher hidrophobicity (28). All measurements were performed at room temperature.

\section{Scanning electron microscopy}

Scanning electron microscopy was carried out to evaluate bacterial adhesion to stainless steel and polyethylene. For these tests, bacterial cultures with $8 \log \mathrm{cfu} \mathrm{ml}^{-1}$ remained in contact with the polyethylene for $15 \mathrm{~min}$ and with the stainless steel for $30 \mathrm{~min}$. The coupons were prepared as follows: coupons with adhered cells were washed three times for 30 min with 0.2 mmol $1^{-1}$ phosphate buffer and distillated water (1:1), fixed with $12 \%(\mathrm{v} / \mathrm{v})$ glutaraldehyde for 7 days, and washed again with $0.2 \mathrm{mmol} \mathrm{l}^{-1}$ phosphate buffer. The coupons were dehydrated with acetone in increasing concentrations of 30 to $100 \%$, with a pause of 10 and 20 minutes. After drying in room temperature, the coupons were submitted to critical point drying with liquid $\mathrm{CO}_{2}$, in the Balzers CPD030 equipment (Balzers Union Ltd, Balzers, Lichtenstein). The coupons were covered with gold (metallization) in Balzers SCD050 equipment (Balzers Union Ltd, Balzers, Lichtenstein), and observed in a Jeol JSM-6060 scanning electron microscope (Jeol, Tokyo, Japan).

\section{Resistance of adhered cells to sanitizers}

The stainless steel and polyethylene coupons were immersed for $15 \mathrm{~min}$ in bacterial suspensions of each Salmonella serovar. After that, the coupons were transferred to recipients containing $10 \mathrm{ml}$ of the sanitizers in the following concentrations: $150,300,450,750$, and $1500 \mathrm{mg} \mathrm{kg}^{-1}$ PAA; 40, 120, 200, 400, and $800 \mathrm{mg} \mathrm{kg}^{-1} \mathrm{NaOCl} ; 400,600,2000$, and $4000 \mathrm{mg} \mathrm{kg}^{-1}$ Quat. To each sanitizer tube, $1 \mathrm{ml}$ of bovine serum albumin $\left(10 \mathrm{mg} \mathrm{ml}^{-1}\right)$ was added. Each coupon was separately immersed for $10 \mathrm{~min}$ in each sanitizer concentration, and then immersed again in neutralizing solutions for 30 seconds (12). The neutralizing solutions were $0.6 \%(\mathrm{w} / \mathrm{v})$ sodium thiosulfate to $\mathrm{NaOCl}$ and PAA, and $0.5 \%$ (v/v) Tween 80 to Quat $(12,13)$. The samples were then transferred to PBS and immediately sonicated for two periods of $10 \mathrm{~min}$. The coupons used as control were treated with distillated water instead of sanitizers. Samples were submitted to decimal dilutions, and $20 \mu \mathrm{l}$ of each dilution were plated in NA, for determination of viable cell counts (19).

\section{Statistical analysis}

Data were subjected to variance analysis (ANOVA) and Tukey's test to detect significant differences Differences were considered significant when $P<0.05$. 


\section{RESULTS}

\section{Evaluation of the adhesion capability}

The three serovars of Salmonella presented similar adhered cell counts, ranging from 5.27 to $5.89 \log \mathrm{cfu} \mathrm{cm}^{-2}$, on stainless steel, and from 4.8 to $6.45 \log \mathrm{cfu} \mathrm{cm}^{-2}$, on polyethylene (Table 1). The time of exposure did not influence $(P<0.05)$ the counts of adhered cells on both surfaces. $S$. Bredeney adhered better to polyethylene, whereas $S$. the other serovars (result not shown).
Typhimurium to stainless steel $(P<0.05) . S$. Enteritidis revealed similar adhesion levels to both materials. Scanning Electron Microscopy revealed that polyethylene presented a much deeper and irregular surface than the stainless steel (Figure $1 \mathrm{~A}$ and B). In general, microorganisms presented similar distribution on the materials, except by the fact of $S$. Enteritidis was able to form clusters of cells on stainless steel (Figure $1 \mathrm{C}$ ) and on polyethylene (Figure $1 \mathrm{D}$ ), what was not observed by

Table 1. Adhesion of Salmonella serovars on stainless steel and polyethylene coupons.*

\begin{tabular}{cccc}
\hline $\begin{array}{c}\text { CONTACT TIME } \\
\text { (MIN) }\end{array}$ & S. Bredeney & S. Typhimurium & S. Enteritidis \\
\hline Stainless steel & $5.63 \pm 0.34$ & $5.68 \pm 0.10$ & \\
15 & $5.70 \pm 0.55$ & $5.66 \pm 0.54$ & $5.27 \pm 0.17$ \\
30 & $5.75 \pm 0.51$ & $5.89 \pm 0.15$ & $5.53 \pm 0.15$ \\
60 & & & \\
Polyethylene & $6.22 \pm 0.15$ & $5.30 \pm 0.01$ & $4.80 \pm 0.41$ \\
15 & $6.39 \pm 0.08$ & $5.46 \pm 0.15$ & $5.17 \pm 0.12$ \\
30 & $6.45 \pm 0.01$ & $5.64 \pm 0.04$ & $5.19 \pm 0.21$ \\
60 & & & \\
\hline
\end{tabular}

$*$ Values $\left(\log _{10} \mathrm{cfu} \mathrm{cm}^{-2}\right)$ are the means \pm standard deviations of three independent experiments.
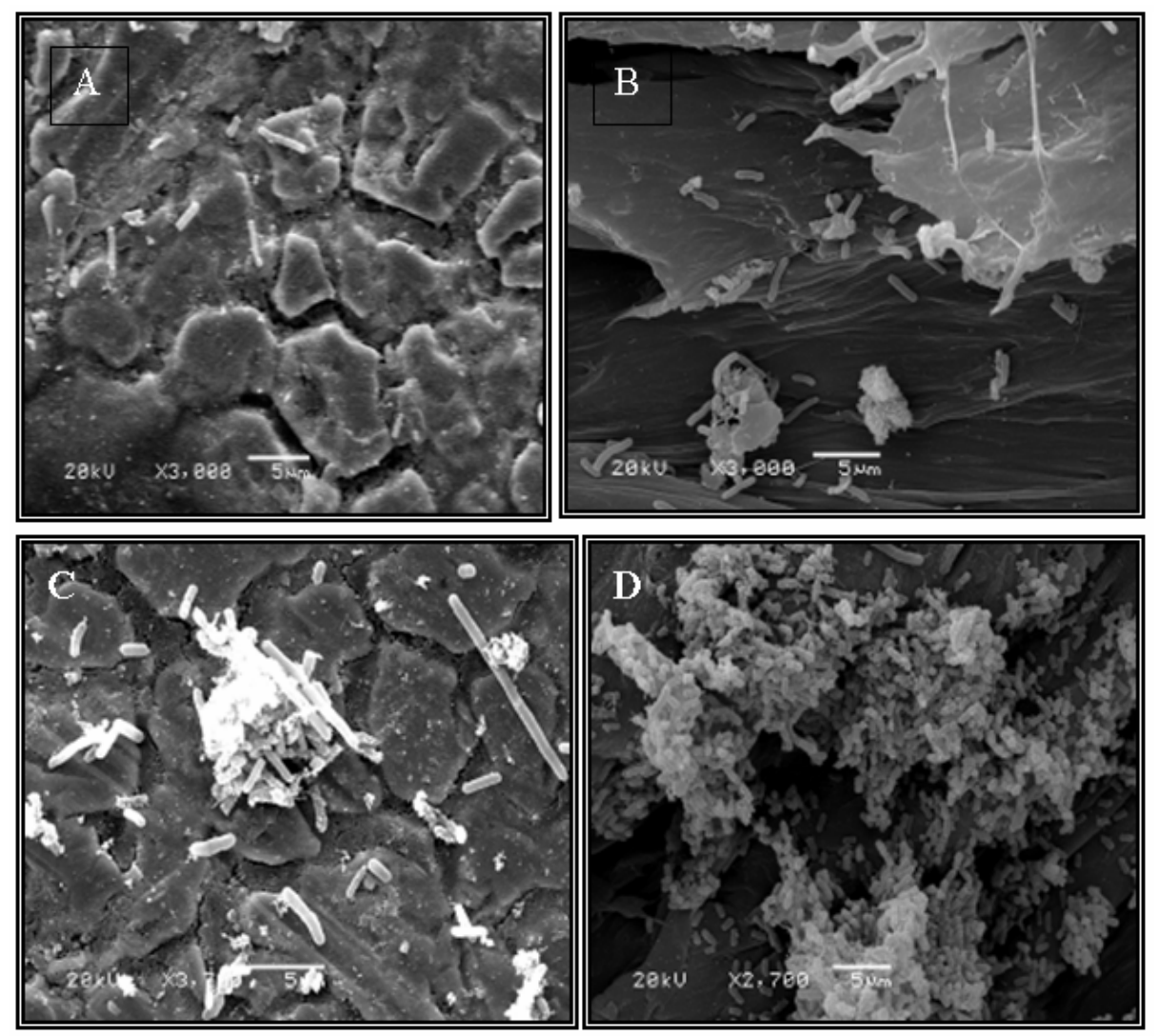

Figure 1. Scanning electron microscopy (SEM) showing the surfaces of stainless steel (A) and polyethylene (B) coupons, and the clusters of adhered cells of $S$. Enteritidis on stainless steel (C) and on polyethylene (D). 


\section{Hydrophobicity evaluation}

The drop contact angle measurements on polyethylene surfaces were higher than those observed on stainless steel (Table 2 and Figure 5), indicating that polyethylene was more hydrophobic than stainless steel.

An expressive reduction of the sessile drop angle on polyethylene could be observed when those obtained with no inoculated $\mathrm{BHI}\left(60.7^{\circ} \pm 2.5\right)$ were compared with $\mathrm{BHI}$ containing $S$. Enteritidis cells $\left(44^{\circ} \pm 2.8\right)$. These results suggest that $S$. Enteritidis cells present hydrophilic properties.
Suspensions of $S$. Enteritidis showed similar angles on both stainless steel and polyethylene, while $S$. Typhimurium and $S$. Bredeney showed higher drop angles on polyethylene (Table 2).

The three Salmonella serovars presented similar drop angle measurements on stainless steel. In contrast, the same result was not observed for polyethylene, once the drop angle measurement for $S$. Enteritidis culture was statistically different from the other two serovars $(P<0.05)$.

Table 2. Measurement of sessile drop angle in stainless steel and polyethylene surfaces of $S$. Typhimurium, $S$. Enteritidis and $S$. Bredeney cultures.*

\begin{tabular}{|c|c|c|c|c|c|}
\hline & $\begin{array}{l}\text { DISTILLED } \\
\text { WATER }\end{array}$ & BHI† & BHI+ST & BHI+SE & BHI+SB \\
\hline Stainless steel & $44.5^{\circ} \pm 0.7$ & $50.5^{\circ} \pm 0.7$ & $45^{\circ} \pm 1.4$ & $42^{\circ} \pm 1.4$ & $44^{\circ} \pm 1.4$ \\
\hline Polyethylene & $52.2^{\circ}+1.8$ & $60.7^{\circ}+2.4$ & $51^{\circ}+0.0$ & $44^{\circ}+2.8$ & $52^{\circ}+1.4$ \\
\hline
\end{tabular}

* Values are the means \pm standard deviations of three independent determinations.

$\dagger$ BHI, Brain Heart Infusion broth; ST, S. Typhimurium; SE, S. Enteritidis; SB, S. Bredeney.
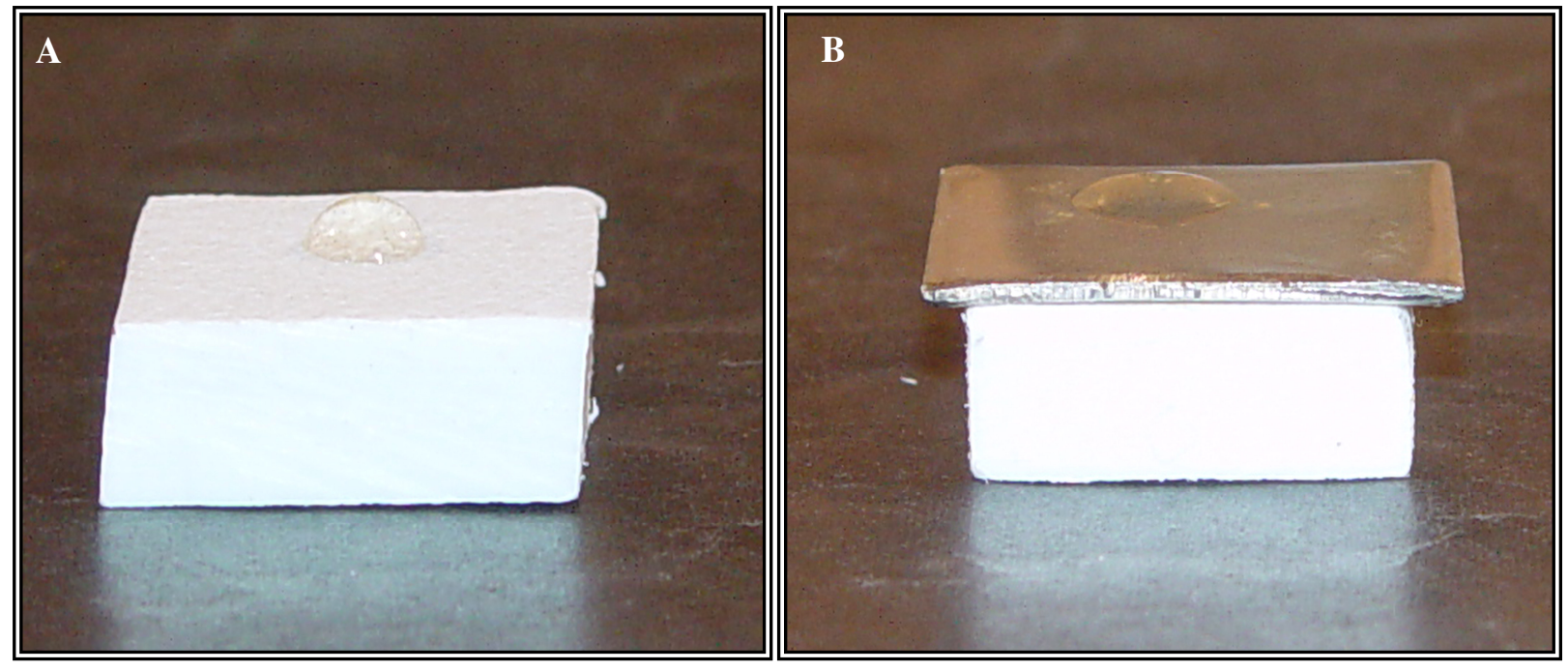

Figure 5. Coupons of polyethylene (A) and stainless steel (B) with a drop of Brain Heart Infusion broth, used for hydrophobicity measureme the sessile drop method. 


\section{Resistance of adhered cells to sanitizers}

The survival of the three Salmonella serovars to PAA is shown in Fig. 2 and Table 3. S. Bredeney, S. Typhimurium, and $S$. Enteritidis were the most resistant to disinfection when adhered to polyethylene, under all concentrations of PAA tested (Fig. 2A, 2B, and 2C). The use of PAA at 750 and 1500 $\mathrm{mg} \mathrm{kg}$ caused a significant reduction in the counts of $S$. Bredeney and $S$. Enteritidis on stainless steel when compared to polyethylene $(P<0.05)$. The reductions rates varied approximately of 2.4 to $3.3 \log \mathrm{cm}^{-2}$, on polyethylene, and of 2.5 to $4.0 \log \mathrm{cm}^{-2}$, on stainless steel.

The survival of the three Salmonella serovars adhered to polyethylene and stainless steel after treatment with different concentrations of $\mathrm{NaOCl}$ is illustrated in Fig. 3 and Table 3. S. Bredeney (Fig. 3A) and S. Typhimurium (Fig. 3B) showed similar resistance to $\mathrm{NaOCl}$ when adhered to polyethylene or stainless steel, under all $\mathrm{NaOCl}$ concentrations tested. However, the final counts of $S$. Bredeney were higher than the final counts of $S$. Typhimurium. $S$. Enteritidis (Fig. 3C) was more resistant to the disinfection of $\mathrm{NaOCl}\left(800 \mathrm{mg} \mathrm{kg}^{-1}\right)$ on polyethylene, once-reduction rates were smaller $\left(2.7 \log \mathrm{cm}^{-2}\right)$ than the reduction rates of the other serovars $\left(3.1 \log \mathrm{cm}^{-2}\right.$ for $S$. Bredeney and $3.7 \log \mathrm{cm}^{-2}$ for $S$. Typhimurium).

The survival of the three Salmonella serovars after the treatment with different concentrations of Quat is presented in Fig. 4 and Table 3. Overall, the microorganisms presented higher numbers of survivors on polyethylene treated with biocides than on stainless steel. When adhered to polyethylene, the serovars $S$. Typhimurium (Fig. 4B) and S. Enteritidis (Fig. 4C) were more resistant to Quat $(P<0.05)$ than $S$. Bredeney (Fig 4A), in all concentrations tested. $S$. Enteritidis showed the smaller reduction rate $\left(1.22 \log \log \mathrm{cm}^{-2}\right)$ after the disinfection of polyethylene with Quat compared to $S$. Typhimurium $\left(2.52 \log \mathrm{cm}^{-2}\right.$ ) and $S$. Bredeney (4.12 $\log \mathrm{cm}^{-2}$ ). On stainless steel, $S$. Typhimurium was more resistant to Quat than the other serovars, once the maximum reduction observed was $4.44 \log \mathrm{cm}^{-2}$, whereas $S$. Bredeney presented $5.21 \log \mathrm{cm}^{-2}$ reduction and $S$. Enteritidis $6.24 \log \mathrm{cm}^{-2}$ reduction.

When the three Salmonella serovars were exposed to PAA concentrations of $1500 \mathrm{mg} \mathrm{kg}^{-1}$ and $750 \mathrm{mg} \mathrm{kg}^{-1}$ in suspension tests (with planktonic cells), this biocide was able to completely inactivate all microorganisms within 5 minutes. Indeed, Quat at $4000 \mathrm{mg} \mathrm{kg}^{-1}$ and $2000 \mathrm{mg} \mathrm{kg}^{-1}$ and $\mathrm{NaOCl}$ at $800 \mathrm{mg} \mathrm{kg}^{-1}$ were able to inactivate all Salmonella serovars in few minutes. However, $S$. Enteritidis was the only serovar that resisted to $200 \mathrm{mg} \mathrm{kg}^{-1}$ of $\mathrm{NaOCl}$ for 15 minutes of exposure in suspension tests (results not shown).
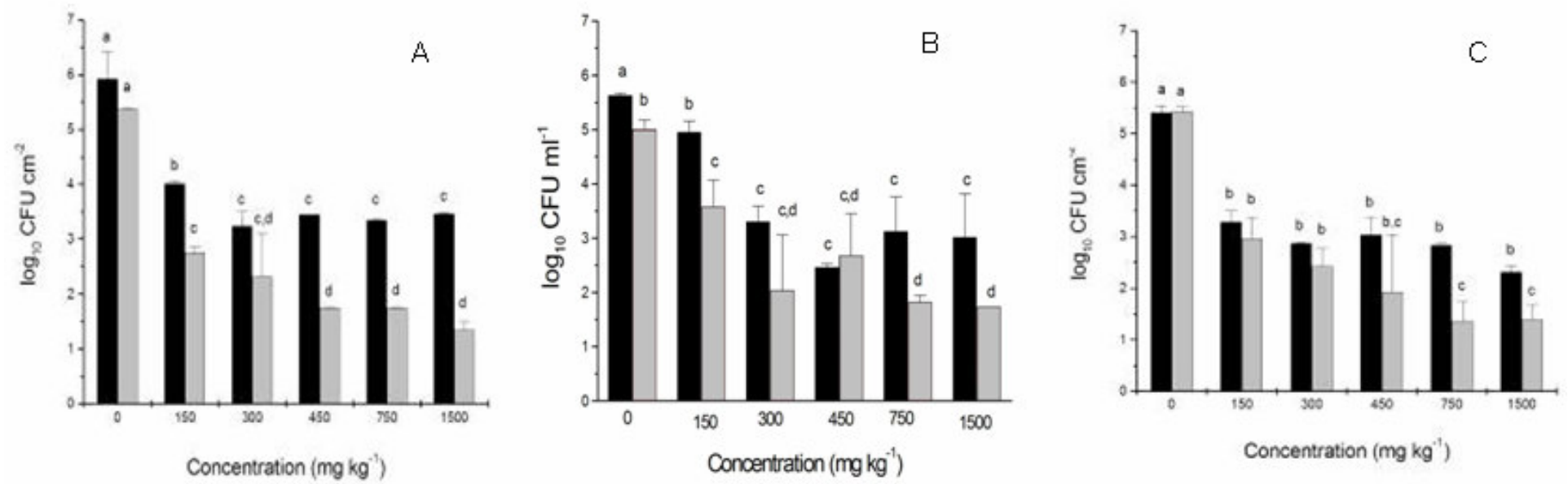

Figure 2. Survival of $S$. Bredeney (A), $S$. Typhimurium (B) and $S$. Enteritidis (C) adhered to stainless steel (grey columns) and polyethy (black columns) coupons after treatment with peracetic acid for $10 \mathrm{~min}$. 
Table 3. Number of survivors $\left(\log \mathrm{CFU} / \mathrm{cm}^{2}\right.$ ) of three Salmonella serovars adhered to stainless steel (ss) and polyethylene (pol) coupons after 10 minutes of treatment with different concentrations of peracetic acid (PAA), sodium hypochlorite (NaOCl), and quaternary ammonium (Quat) biocides.

\begin{tabular}{|c|c|c|c|c|c|c|}
\hline \multicolumn{7}{|c|}{$\begin{array}{l}\text { PERACETIC ACID (PAA) } \\
\end{array}$} \\
\hline \multirow[t]{2}{*}{$\begin{array}{c}\text { Concentrations } \\
\mathrm{mg} \mathrm{Kg}^{-1}\end{array}$} & \multicolumn{2}{|c|}{$\begin{array}{c}S . \text { Bredeney } \\
\left(\log \text { CFU } / \mathrm{cm}^{2}\right)\end{array}$} & \multicolumn{2}{|c|}{$\begin{array}{c}\text { S. Typhimurium } \\
\left(\log \text { CFU } / \mathrm{cm}^{2}\right)\end{array}$} & \multicolumn{2}{|c|}{$\begin{array}{c}S . \text { Enteritidis } \\
\left(\log \mathrm{CFU} / \mathrm{cm}^{2}\right)\end{array}$} \\
\hline & SS & pol & ss & pol & SS & poly \\
\hline Control & $5.36 \pm 0.02$ & $5.91 \pm 0.49$ & $5.01 \pm 0.17$ & $5.63 \pm 0.04$ & $5.42 \pm 0.10$ & $5.40 \pm 0.13$ \\
\hline 150 & $2.75 \pm 0.00$ & $4.01 \pm 0.05$ & $3.58 \pm 0.49$ & $4.96 \pm 0.20$ & $2.96 \pm 0.41$ & $3.28 \pm 0.21$ \\
\hline 300 & $2.31 \pm 0.79$ & $3.23 \pm 0.26$ & $2.04 \pm 0.42$ & $3.31 \pm 0.28$ & $2.42 \pm 0.35$ & $2.86 \pm 0.02$ \\
\hline 450 & $1.74 \pm 0.00$ & $3.44 \pm 0.004$ & $2.68 \pm 0.77$ & $2.47 \pm 0.06$ & $1.92 \pm 1.10$ & $3.02 \pm 0.35$ \\
\hline 750 & $1.74 \pm 0.00$ & $3.34 \pm 0.02$ & $1.83 \pm 0.12$ & $3.13 \pm 0.63$ & $1.35 \pm 0.39$ & $2.83 \pm 0.03$ \\
\hline 1500 & $1.33 \pm 0.15$ & $3.46 \pm 0.01$ & $1.74 \pm 0.00$ & $3.02 \pm 0.80$ & $1.38 \pm 0.29$ & $2.31 \pm 0.11$ \\
\hline \multicolumn{7}{|c|}{ SODIUM HYPOCHLORITE (NAOCL) } \\
\hline \multirow[t]{2}{*}{$\begin{array}{c}\text { Concentrations } \\
\mathrm{mg} \mathrm{Kg}^{-1}\end{array}$} & \multicolumn{2}{|c|}{$\begin{array}{l}S . \text { Bredeney } \\
\left(\log \text { CFU/cm }{ }^{2}\right)\end{array}$} & \multicolumn{2}{|c|}{$\begin{array}{c}\text { S. Typhimurium } \\
\left(\log \mathrm{CFU} / \mathrm{cm}^{2}\right)\end{array}$} & \multicolumn{2}{|c|}{$\begin{array}{c}S . \text { Enteritidis } \\
\left(\log \mathrm{CFU} / \mathrm{cm}^{2}\right)\end{array}$} \\
\hline & SS & pol & ss & pol & SS & poly \\
\hline Control & $5.73 \pm 0.23$ & $5.70 \pm 0.35$ & $5.55 \pm 0.01$ & $5.56 \pm 0.06$ & $5.54 \pm 0.36$ & $5.36 \pm 0.19$ \\
\hline 20 & $5.56 \pm 0.03$ & $5.33 \pm 0.07$ & $5.06 \pm 0.14$ & $5.43 \pm 0.05$ & $5.35 \pm 0.24$ & $5.18 \pm 0.35$ \\
\hline 40 & $4.88 \pm 0.83$ & $4.79 \pm 0.63$ & $4.72 \pm 0.02$ & $5.00 \pm 0.03$ & $5.02 \pm 0.09$ & $4.34 \pm 0.09$ \\
\hline 120 & $3.52 \pm 0.02$ & $3.86 \pm 0.60$ & $2.93 \pm 0.08$ & $4.78 \pm 0.31$ & $3.26 \pm 0.39$ & $4.26 \pm 0.11$ \\
\hline 200 & $3.42 \pm 0.05$ & $3.83 \pm 0.74$ & $2.55 \pm 0.28$ & $3.81 \pm 0.47$ & $3.68 \pm 0.06$ & $4.18 \pm 0.06$ \\
\hline 400 & $2.37 \pm 0.08$ & $3.12 \pm 0.09$ & $2.72 \pm 0.00$ & $2.80 \pm 0.01$ & $2.68 \pm 0.11$ & $3.93 \pm 0.03$ \\
\hline 800 & $2.54 \pm 0.04$ & $2.59 \pm 0.61$ & $1.38 \pm 0.21$ & $1.88 \pm 0.25$ & $1.03 \pm 0.00$ & $2.62 \pm 0.08$ \\
\hline \multicolumn{7}{|c|}{ QUATERNARY AMMONIUM (QUAT) } \\
\hline \multirow[t]{2}{*}{$\begin{array}{c}\text { Concentrations } \\
\mathrm{mg} \mathrm{Kg}^{-1}\end{array}$} & \multicolumn{2}{|c|}{$\begin{array}{l}S . \text { Bredeney } \\
\left(\log \text { CFU/cm }{ }^{2}\right)\end{array}$} & \multicolumn{2}{|c|}{$\begin{array}{c}\text { S. Typhimurium } \\
\left(\log \text { CFU } / \mathrm{cm}^{2}\right)\end{array}$} & \multicolumn{2}{|c|}{$\begin{array}{l}S . \text { Enteritidis } \\
\left(\log \mathrm{CFU} / \mathrm{cm}^{2}\right)\end{array}$} \\
\hline & SS & pol & SS & pol & SS & poly \\
\hline Control & $5.73 \pm 0.23$ & $5.70 \pm 0.35$ & $5.34 \pm 0.09$ & $5.12 \pm 0.14$ & $6.24 \pm 0.98$ & $5.29 \pm 0.60$ \\
\hline 200 & $4.88 \pm 0.83$ & $4.79 \pm 0.63$ & $1.59 \pm 2.25$ & $4.14 \pm 1.18$ & $2.28 \pm 0.27$ & $5.06 \pm 0.25$ \\
\hline 400 & $3.52 \pm 0.02$ & $3.86 \pm 0.60$ & $1.66 \pm 2.34$ & $4.11 \pm 1.81$ & $1.74 \pm 0.65$ & $5.12 \pm 0.19$ \\
\hline 600 & $3.42 \pm 0.05$ & $3.83 \pm 0.74$ & $2.86 \pm 0.98$ & $3.67 \pm 1.01$ & $1.59 \pm 0.21$ & $5.19 \pm 0.18$ \\
\hline 2000 & $2.37 \pm 0.08$ & $3.12 \pm 0.09$ & $0.90 \pm 1.28$ & $2.83 \pm 0.21$ & $0.87 \pm 1.23$ & $4.89 \pm 0.31$ \\
\hline 4000 & $0.52 \pm 0.73$ & $1.58 \pm 0.62$ & $0.92 \pm 1.31$ & $2.60 \pm 0.14$ & ND & $4.07 \pm 1.36$ \\
\hline
\end{tabular}
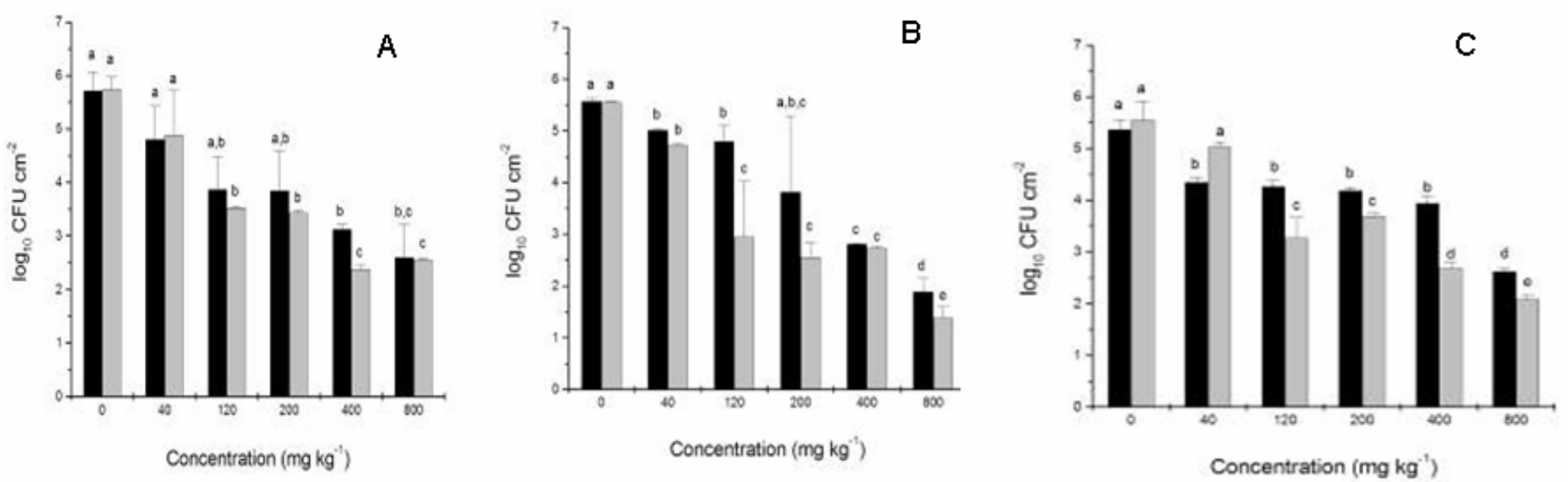

Figure 3. Survival of $S$. Bredeney (A), S. Typhimurium (B) and $S$. Enteritidis (C) adhered to stainless steel (grey columns) and polyethylene (black columns) coupons after treatment with sodium hypochlorite for $10 \mathrm{~min}$. 

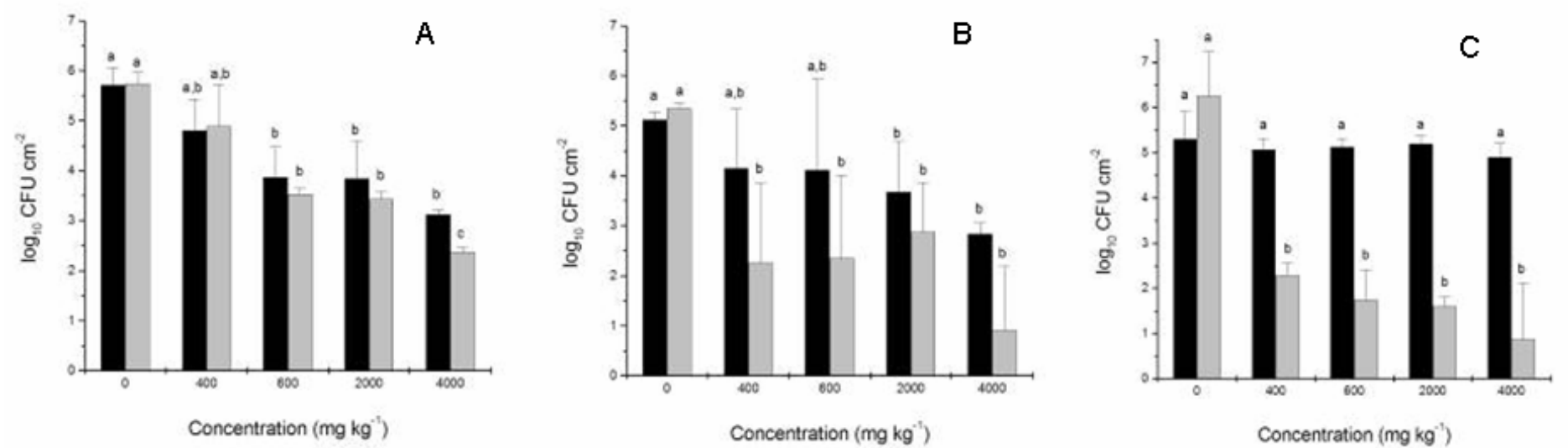

Figure 4. Survival of $S$. Bredeney (A), S. Typhimurium (B) and $S$. Enteritidis (C) adhered to stainless steel (grey columns) and polyethylene (black columns) coupons after treatment with Quat for $10 \mathrm{~min}$.

\section{DISCUSSION}

Salmonella serovars tested in this study showed an adhesion capacity between 5.0 and $6.0 \log \mathrm{cfu} \mathrm{cm}^{-2}$ on stainless steel, and between 5.0 and $6.45 \log \mathrm{cfu} \mathrm{cm}^{-2}$ on polyethylene. These results are in agreement with Joseph et al. (12) who reported that Salmonella sp. were able to form biofilms of about $5 \log \mathrm{cfu} \mathrm{cm}^{-2}$ on stainless steel and $7 \log \mathrm{cfu} \mathrm{cm}^{-2}$ on polyethylene. Similar results were also observed by Oliveira $e t$ al. (25) studying the adhesion of different strains of $S$. Enteritidis to stainless steel SS 304. In our study the tested serovars presented no significant differences in adhesion levels when exposed by different times on stainless steel or polyethylene, suggesting that the exposure periods did not influence the final amount of adhered cells. Hood and Zotolla (11) quantified biofilms formed by many bacteria, including $S$. Typhimurium on stainless steel for contact periods of 1 to 72 hours, and found adhesion levels around $5 \log \mathrm{cfu} \mathrm{cm}^{-2}$. Those results suggested that the microorganism adherence did not increase after one hour of contact.

Stainless steel and polyethylene are widely used in food processing equipments, and are able to be colonized by Salmonella and other microorganisms. Adhered bacteria to equipment surfaces can have the potential to act as sources of microbial contamination, which may compromise food quality and represent a significant health hazard (1, 5, 23). According to our results, even short periods of contact, such as $15 \mathrm{~min}$, may allow a considerable number of Salmonella cells to adhere, demonstrating a potential risk of cross contamination during food handling.

In the present study, polyethylene was shown to be more hydrophobic than stainless steel, once the drops in contact with polyethylene surface presented higher inclination angles. Hydrophobic materials are reported as surfaces that provide a greater bacterial adherence $(6,15)$. The greater hydrophobicity of polyethylene compared to stainless steel can be an explanation to the higher counts of adhered Salmonella cells on polyethylene as observed in our results.

Through the scanning electron microscopy, some irregularities in the stainless steel topography could be observed. Using the same method of microscopy, Barnes et al. (1) compared Staphylococcus aureus adherence to polished stainless steel and to rough stainless steel and observed a higher number of $S$. aureus adhered to the rough surface. As for adherence of $S$. Enteritidis to irregular surfaces, Oliveira $e t$ al. (24) suggested that the deepness of the irregularities were more relevant than the distance between them. Our results indicated that polyethylene presented a more irregular surface and deeper irregularities than the stainless steel, explaining the higher counts of Salmonella adhered to polyethylene. 
In the past few years, a considerable progress has been made in order to understand the response of different bacteria to biocides (18). The evaluation of the resistance of microorganisms such as Salmonella to sanitizers is very important, once the correct use of such compounds can avoid foodborne outbreaks. The experiments carried out with PAA proved that the three serovars of Salmonella were not completely inactivated by the disinfection process, even when the concentration prescribed by the manufacturer $\left(1500 \mathrm{mg} \mathrm{kg}^{-}\right.$ ${ }^{1}$ ) is used. After disinfection with PAA, at least $1 \log \mathrm{cm}^{-2}$ of the serovars remained on the stainless steel surfaces. On polyethylene, $2 \log \mathrm{cm}^{-2}$ of $S$. Enteritidis and $3 \log \mathrm{cm}^{-2}$ of $S$. Bredeney were still viable. When the resistance of adhered Salmonella to the tested surfaces is compared, a smaller decimal reduction was noticed in polyethylene after the disinfection process. This may be related to a greater irregularity of this surface. Rossoni and Gaylarde (26) evaluated the PAA efficacy in the inactivation of Escherichia coli, Pseudomonas fluorescens and Staphylococcus aureus adhered to stainless steel, after one hour contact with the cultures. They reported $1 \log$ reduction of $E$. coli and $P$. fluorescens using a concentration of $250 \mathrm{mg} \mathrm{kg}^{-1}$ PAA. With a concentration of $1000 \mathrm{mg} \mathrm{kg}{ }^{-1}, S$. aureus populations were reduced in $1 \mathrm{log}$, whereas the population of E. coli was reduced in $2 \log$ after 10 minutes in contact with PAA. Those authors reported that a higher decimal reduction was observed when the concentration used was increased, confirming the data obtained in the present work.

$\mathrm{NaOCl}$ is a disinfectant widely used in Brazil due to its low cost and broad spectrum. The FDA (Food and Drug Administration) permits its use as a biocide agent for food contact surfaces in concentrations above $200 \mathrm{mg} \mathrm{kg}^{-1}$. When the Salmonella were adhered to stainless steel, a $4 \log \mathrm{cm}^{-2}$ reduction was achieved for $S$. Enteritidis and $S$. Typhimurium after treatment with $\mathrm{NaOCl}$, whereas lower reductions were observed on polyethylene. Higher reductions rates were described by Joseph et al. (12), who analyzed the sensitivity of biofilms formed by Salmonella sp. to biocides. On a polyethylene sample treated with $100 \mathrm{mg} \mathrm{kg}^{-1}$ chlorine, $7 \mathrm{log}$ cfu $\mathrm{cm}^{-2}$ of Salmonella were completely inactivated after 20 min in contact with the sanitizer. For stainless steel, $15 \mathrm{~min}$ were sufficient to inactivate $5 \log \mathrm{cfu} \mathrm{cm}^{-2}$. Rossoni and Gaylarde (26) evaluated the effect of 100 and $200 \mathrm{mg} \mathrm{kg}^{-1}$ $\mathrm{NaOCl}$ on bacterial cultures adhered to stainless steel, for a period of $10 \mathrm{~min}$. The number of $E$. coli cells adhered to stainless steel was reduced from 5 to $3 \log \mathrm{cfu} \mathrm{cm}^{-2}$. Another important observation is the fact that there were no significant differences between 100 and $200 \mathrm{mg} \mathrm{kg}^{-1}$ of $\mathrm{NaOCl}$ when the cells were adhered to stainless steel. Similar results were presented in our study, because the reduction rates of $S$. Enteritidis and $S$. Bredeney exposed to 120 and $200 \mathrm{mg} \mathrm{kg}^{-1}$ were similar. It is important to note that these $\mathrm{NaOCl}$ concentrations are the ones generally recommended in Brazil for disinfection of food contact surfaces and cleaning cloths used in food preparation. Based on our results, more than $3 \log$ $\mathrm{cfu} \mathrm{cm}^{-2}$ of the Salmonella serovar tested remained viable after disinfection of the surfaces. In addition, -smaller reduction rates were observed for $S$. Enteritidis SE86, a strain frequently involved in salmonellosis is RS.

Sinde and Carbalo (27) observed that Quat was very efficient against Salmonella sp., but the bacterial reduction was also dependent on the properties of the material studied. In our work, all serovars showed a high resistance to Quat specially when adhered to polyethylene. It was mainly noted for $S$. Enteritidis SE86, once the population was almost not affected when adhered to polyethylene disinfected by different concentrations of Quat. Borowsky et al. (3) evaluated the resistance of $S$. Typhimurium isolated from swine to Quat. The test was made in suspension with no addition of organic matter and the levels of Quat used were 0.3 and $0.6 \mathrm{mg} \mathrm{l}^{-1}(15 \mathrm{~g} / 100$ $\mathrm{ml}$ of active compound). According to those authors, $S$. Typhimurium samples were resistant to both concentrations after $5 \mathrm{~min}$ of exposure, but no resistant samples were found after 15 min.

In conclusion, the three serovars of Salmonella presented an important capacity of adhesion to stainless steel and to polyethylene, even in a short period of time. The sanitizers PAA, $\mathrm{NaOCl}$ and Quat did not inactivate all the cells adhered 
to both materials, and polyethylene surfaces presented to be more difficult to disinfect than stainless steel. In some of the conditions evaluated, $S$. Enteritidis SE86 was more resistant than the other strains tested, especially to $\mathrm{NaOCl}$ and Quat. This resistance could explain the frequent involvement of $S$. Enteritidis SE86 in a great number of foodborne salmonellosis occurred in Southern Brazil.

\section{ACKNOWLEDGEMENTS}

Authors thank Dr. M.P. Geimba (PUCRS) and Dr. M.R.I. Cardoso (UFRGS) for kindly providing the bacterial strains. T.R.M. Machado thanks CAPES, Brazil, for the M.Sc. fellowship.

\section{REFERENCES}

1. Barnes, L.M.; Lo, M.F.; Adams, M.R.; Chamberlain, A.H.L. (1999). Effect of milk proteins on adhesion of bacteria to stainless steel surfaces. Appl. Environ. Microbiol. 65 (10), 4543-4548.

2. Beresford, M.R.; Andrews, P.W.; Shama, G. (2001). Listeria monocytogenes adheres to many materials found in food-processing environments. J. Appl. Microbiol. 90 (6), 1000-1005.

3. Borowsky, L.M.; Bessa, M.C.; Cardoso, M.R.I.; Avancini, C.A.M. (2006). Sensibilidade e resistência de amostras de Salmonella Typhimurium isoladas de suínos abatidos no Rio Grande do Sul/Brasil frente aos desinfetantes químicos quaternário de amônio e iodofor. Cienc. Rural. 36 (5), 1474-1479.

4. Carballo, J.; Ferreiros, C.M.; Criado, M.T. (1992). Factor analysis in the evaluation of the relationship between bacterial adherence to biomaterials and changes in free energy. J. Biomat. Appl. 7 (2), 130-141.

5. Costa, P.D.; Andrade, N.J.; Brandão, S.C.C.; Passos, F.J.V.; Soares, N.F.F. (2006). ATP- Bioluminescence assay as an alternative for hygiene-monitoring procedures of stainless steel milk contact surfaces. Braz. J. Microbiol. 37 (3), 345-349.

6. Djordjevic, D.; Wiedmann, M.; Mclandsborough, L.A. (2002). Microtiter plate assay for assessment of Listeria monocytogenes biofilm formation. Appl. Environ. Microbiol. 68 (6), 2950-2958.

7. Frank, J.F.; Chmielewski, R.A.N. (2003). Biofilm formation and control in food processing facilities. Compr. Rev. Food Sci. Food Safety 2 (1), 22-32.

8. Geimba, M.P.; Tondo, E.C.; Oliveira, F.A.; Canal, C.W.; Brandelli, A. (2004). Serological characterization and prevalence of $s p v \mathrm{R}$ genes in Salmonella isolated from foods involved in outbreaks in Brazil. $J$. Food Protec. 67 (6), 1229-1233.
9. Holah, J.T.; Thorpe, R.H. (1990). Cleanability in relation to bacterial retention on unused abraded domestic sink materials. J. Appl. Microbiol. 69 (4), 599-608.

10. Holah, J.T.; Higgs, C.; Robinson, S.; Worthington, D.; Spenceley, H. (1990). A conductance based surface disinfection test for food hygiene. Lett. Appl. Microbiol., 11 (5), 255-259.

11. Hood, S.K.; Zottola, E.A.A. (1997). Adherence to stainless steel by foodborne microorganisms during growth in model food systems. Int. J. Food Microbiol. 37 (2-3), 145-153.

12. Joseph, B.; Otta, S.K.; Karunasagar, I. (2001). Biofilm formation by Salmonella spp. on food contact surface and their sensitivity to sanitizers. Int. J. Food Microbiol. 64 (3), 367-372.

13. Kunigk, L.; Almeida, M.C.B. (2001). Action of peracetic acid on Escherichia coli and Staphylococcus aureus in suspension or settled on stailess steel surfaces. Braz. J. Microbiol. 32 (1), 38-41.

14. Kusumaningrum, H.D.; Van Putten, M.M.; Rombouts, F.M.;Beumer, R.R. (2002). Effects of antibacterial dishwashing liquid on foodborne pathogens and competitive microorganisms in kitchen sponges. J. Food Protec. 65 (1), 61-65.

15. Locatelli, C.I.; Englert, G.E.; Kwitko, S.; Simonetti, A.B. (2004). Aderência bacteriana in vitro a lentes intra-oculares de polimetilmetacrilato e de silicone. Arq. Bras. Oftalmol. 67 (2), 241-248.

16. Liu, Y.; Yang, S.F.; Li, Y.; Xu, H.; Qin, L.; Tay, J.H. (2004). The influence of cell and substratum surfaces hydrophobicities on microbial attachment. J. Biotech. 110 (3), 251-256.

17. Marques, S.C.; Rezende, J.G.O.S.; Alves, L.A.F.; Silva, B.C.; Alves, E.; Abreu, L.R.; Piccoli, R.H. (2007). Formation of biofilms by Staphylococcus aureus on stainless steel and glass surfaces and its resistance to some selected chemical sanitizers. Braz. J. Microbiol. 38 (3), 538-543.

18. McDonnell, G.; Russel, A.D. (1999). Antiseptics and disinfectants: activity, action and resistance. Clin. Microbiol. Rev. 12 (1), 147-179.

19. Milles, A.A.; Misra, S.S. (1938). Estimation of the bactericide power of the bloods. J. Hyg. 38, 732-749.

20. Mürmann, L.; Santos, M.C.; Longaray, S.M.; Both, J.M.C.; Cardoso, M. (2008). Quantification and molecular characterization of Salmonella isolated from food samples involved in salmonellosis outbreaks in Rio Grande do Sul, Brazil. Braz. J. Microbiol. 39 (3), 529-534.

21. Oliveira, F.A.; Frazzon, A.P.G.; Brandelli, A.; Tondo, E.C. (2007). Use of PCR-ribotyping, RAPD, and antimicrobial resistance for typing of Salmonella enteritidis involved in food-borne outbreaks in Southern Brazil. J. Infect. Develop. Countr. 1 (2), 170-176.

22. Oliveira, F.A.; Geimba, M.P.; Pasqualotto, A.P.; Brandelli, A.; Pasquali, G.; Silva, W.P.; Tondo, E.C. (2009). Clonal relationship among Salmonella enterica serovar Enteritidis involved in foodborne outbreaks in Southern Brazil. Food Control 20 (6), 606-610.

23. Oliveira, M.M.M.; Brugnera, D.F.; Alves, E.; Piccoli, R.H. (2010). Biofilm formation by Listeria monocytogenes on stainless steel surface and biotransfer potential. Braz. J. Microbiol. 41 (1), 97-106. 
24. Oliveira, K.; Oliveira, T.; Teixeira, P.; Azeredo, J.; Henriques, M.; Oliveira, R. (2006). Comparison of the adhesion ability of different Salmonella Enteritidis serotypes to materials used in kitchens. J. Food Prot. 69 (10), 2352-2356.

25. Oliveira, K.; Oliveira, T.; Teixeira, P.; Azeredo, J.; Oliveira, R. (2007). Adhesion of Salmonella Enteritidis to stainless steel surfaces. Braz. J. Microbiol. 38 (2), 318-323.

26. Rossoni, E.M.M.; Gaylarde, C.C. (2000). Comparison of sodium hypochlorite and peracetic acid as sanitizing agents for stainless steel food processing surfaces using epifluorescence microscopy. Int. J. Food Microbiol. 61 (1), 81-85.

27. Sinde, E.; Carballo, J. (2000). Attachment of Salmonella sp. and Listeria monocytogenes to stainless steel, rubber and polytetrafluorethylene: the influence of free energy and the effect of commercial sanitizers. Food Microbiol. 17 (4), 439-447.

28. Skolodowska, A.; Wozniak, M.; Matlakowska, R. (1999). The method of contact angle measurements and estimation of work of adhesion in bioleaching of metals. Biol. Proceed. Online, 1 (3), 114-121. 